\title{
THE ROLE OF INSTITUTE OF FERROUS METALLURGY IN THE DEVELOPMENT OF MATERIALS FOR THE POWER INDUSTRY
}

\author{
ROLA INSTYTUTU METALURGII ŻELAZA W ROZWOJU MATERIAEÓW \\ DLA ENERGETYKI
}

The article presents an outline of the development of the domestic energy sector from the very beginning of its operation. It discusses the impact of the research conducted at the Stanistaw Staszic Institute of Ferrous Metallurgy in Gliwice on the selection of steel grades for operation at elevated and high temperatures for applications in the Polish power industry. The article presents the research and implementation achievements of the research workers of the Institute with the discussion and the purpose of their creation. The article presents the area of joint scientific and research achievements of the Institute of Ferrous Metallurgy with affiliated domestic and foreign research centres, documented by numerous research projects and publications in renowned scientific journals.

Keywords: creep laboratory, steels and alloys for the power industry, diagnostics
Przedstawiono zarys rozwoju krajowej energetyki od początku jej funkcjonowania. Omówiono wptyw badań prowadzonych w Instytucie Metalurgii Żelaza im. Stanistawa Staszica w Gliwicach na dobór gatunków stali do pracy w podwyższonej i wysokiej temperaturze do zastosowań $w$ polskiej energetyce. Zaprezentowano dorobek badawczo-wdrożeniowy pracowników naukowych Instytutu z omówieniem i celowościa ich powstania. Przedstawiono obszar wspólnych dokonań naukowo-badawczych Instytutu Metalurgii Żelaza z zaprzyjaźnionymi krajowymi i zagranicznymi ośrodkami badawczymi, udokumentowanymi licznymi projektami badawczymi i publikacjami $w$ renomowanych czasopismach naukowych.

Stowa kluczowe: stal, odgazowanie próżniowe, ruda żelaza, spiekanie, miedź, cyna, arsen

\section{INTRODUCTION}

The beginning of the use of electricity in Poland dates back to the 1880s. Then, mainly industrial plants began to use generators driven by small steam engines or diesel engines. The electricity obtained in this simple way was used for the own needs of production plants. The first steps in the wider use of electricity in the country were the construction of several municipal power plants at the beginning of the 20th century. An example is the power plant in Radom, founded in 1900 with a capacity of several MW, the power from which was initially used to illuminate the main streets of the city and for the needs of the industry and urban transport. Another example of the emergence of small power plants at the beginning of the 20th century is the Powiśle PP in Warsaw, Łódź PP, and then the construction of power plants in other cities such as Gdańsk, Zabrze, Wrocław and Kraków [1]. At that time, unalloyed (carbon) steels with a maximum operating temperature of $370^{\circ} \mathrm{C}$ and a steam pressure of $4 \mathrm{MPa}$ were used for pressure components [2]. Such progress in the construction of power plants contributed to the commissioning of 280 power plants with a total capacity of $210 \mathrm{MW}$ by 1918. By
1938, approx. 320 power plants with a total capacity of 1,668 MW were already operational. These power plants used steel with the addition of molybdenum as the main material. However, this steel, apart from low creep resistance, showed a tendency to graphitisation at temperatures above $485^{\circ} \mathrm{C}$ as a result of the disintegration of $\mathrm{Fe}_{3} \mathrm{C}$ carbide and precipitation of carbon in the form of graphite, which usually took place after 3-8 years of operation [1]. Hence, the operating parameters of the boilers did not exceed the temperature of $480^{\circ} \mathrm{C}$ and the steam pressure of $10 \mathrm{MPa}$. In order to avoid this phenomenon, and at the same time increase the functional properties at elevated temperatures, chromium was introduced into molybdenum steel in an amount of $\min .0 .5 \%$ [1].

In the 1950s, there was a dynamic development of the Polish energy sector. It was then that the use of steels with the addition of vanadium and an increased content of chromium and molybdenum started, which, however, was not without a reduction in deformability. On the other hand, it allowed for long-term operation of power equipment components at temperatures up to $565^{\circ} \mathrm{C}$. Modern commercial and thermal power plants began to emerge, resulting in a total power increase of approximately 4,000 MW by 1960, 
and by 1970 the total capacity was over 11,000 MW. A significant increase in electricity production in Poland dates back to the beginning of the 1970s. At that time, units with a capacity of $360 \mathrm{MW}$ and two $500 \mathrm{MW}$ units at Kozienice PP were built, which, until the commissioning of a block with supercritical operating parameters at Bełchatów PP in 2010, were the largest power units in the country. In these boilers, 20H12M1F (X20CrMoV12.1) steel was used for the highest levels of steam superheating. The total increase in electricity in the years 1970-1980 was about 12,000 MW. In the next decade of the last century, there was a slowdown in the construction of new power units, where the total installed capacity was about 7,000 MW, mainly due to the construction of the largest Power Plant in Poland in Bełchatów, and completion of the Połaniec Power Plant. The years 1990-2000 were the years of economic recession and initiated economic transformations, and the increase in electricity compared to the previous years was only approximately $2500 \mathrm{MW}[1]$.

Since around 2000, significant progress has been made in the development of the domestic energy sector. It was possible thanks to the worldwide dynamics in the development of new materials for operation at elevated and high temperatures. Many scientific and research centres in the country and abroad, in cooperation with leading manufacturers of power boilers, carried out work on research and implementation of new types of steel for the construction of modern high-efficiency power plants.

The Stanisław Staszic Institute of Ferrous Metallurgy in Gliwice (since 2019, Łukasiewicz Research Network Stanisław Staszic Institute of Ferrous Metallurgy, abbreviated as Łukasiewicz - IMŻ), plays one of the main roles in this briefly characterised history of the Polish power industry.

\section{HISTORY OF RESEARCH ON MATERIALS FOR THE POWER INDUSTRY AT THE INSTITUTE OF FERROUS METALLURGY}

The research and implementation activity related to materials for operating at elevated temperatures at IMŻ was initiated by Zbigniew Borysowski, MSc, Eng. in the 1950s. Borysowski was a former employee of the Lviv University of Technology, who worked at the Institute of Aviation in London during World War II. On his initiative, the first creep laboratory in post-war Poland was established, which was based on the company's own production of creep test machines. These machines were the basic equipment of IMŻ and Racibórz Boiler Factory, Zakłady Mechaniczne in Elblag and the Institute of Precision Mechanics in Warsaw. The activity of Zbigniew Borysowski, an outstanding expert in the selection of research and steel for the power industry, contributed to the implementation of materials based on Western grades in the domestic power industry, which effectively prevented the introduction of steel from the former USSR to the Polish market, the quality and functional properties of which were significantly different from the requirements assumed for them. Zbigniew Borysowski had also been a mentor of younger employees of the Institute, who in the following years held managerial positions, further developing his research and implementation achievements.

The study "Charakterystyki stali - stale do pracy $w$ temperaturach podwyższonych $i$ obniżonych [Steel characteristics
- steels for operation at elevated and lowered temperatures]" (Fig. 1), was an unquestionable achievement of the team led by Zbigniew Borysowski. This study is still in the library of people studying the issue of materials for the energy sector. It contains comprehensive knowledge in the field of mechanical properties and creep strength of Cr-Mo and $\mathrm{Cr}-\mathrm{Mo}-\mathrm{V}$ steels, which are still used in the domestic power industry.

"The School of Materials for the Power Industry" was further developed by the aforementioned younger collaborators of Z. Borysowski: Piotr Miliński, PhD, Eng., Andrzej Tokarz, PhD, Eng. and Professor Janusz Dobrzański, still working at the Institute, who is an undisputed authority in research and diagnostics of materials used for critical components of power boilers.

The creep laboratory, which has been operating continuously since the 1950s, has undergone two thorough modernisations: the first one, in the mid-1970s, and the last one, in 2009 (Fig. 2). The creep test system built at that time, containing many innovative technical solutions, enables remote supervision and control of selected system components. It informs the user online about the defined pre-emergency and emergency states, specifying the type of irregularities and the required response of the operator. Each creep test is started according to a procedure "sewn in" a high-class PLC controller, which practically eliminates operating defects in this area. The Creep Test System, CTS for short, is equipped with a triple power system; directly from the network, from a generator and a UPS. However, the UPS serves only for systemic safe shutdown of the laboratory in the absence of the other two power sources. An important component of the system is the air-conditioning system with ventilation, the purpose of which is to ensure the constant temperature of the elongation sensors at $23 \pm 3^{\circ} \mathrm{C}$. CTS supports 100 single-sample stands with elongation measurement during the test and multi-sample machines for creep tests without measurement of elongation during the test, enabling simultaneous testing in eight preset temperature levels, 100 samples for each temperature level. Multi-sample machines also enable long-term annealing/ageing at preset temperature levels.

Particularly noteworthy is the fact that in the range from 450 to $750^{\circ} \mathrm{C}$, the deviation from the preset test temperature, both along the measurement length of the sample and throughout the test duration (even exceeding tens of thousands of hours), taking into account the influence of the measuring path, is much below $\pm 1^{\circ} \mathrm{C}$. The applied design and IT solutions as well as the use of control systems in the CTS system ensure creep test conditions significantly exceeding the requirements of the applicable standard [3].

The creation of such high standards for testing parameters allows for shortened creep tests in which it is necessary to comply with the preset temperature and the actual temperature on the tested samples. These tests are now commonly used to determine the life and residual life necessary in the evaluation of long-service materials operating under creep conditions. It should be mentioned that this is a method developed at the Creep Laboratory of Łukasiewicz - IMŻ, used to determine residual and disposable residual life, and its reliability has been verified by the results of many years of creep tests [4-6].

Also, the measurement accuracy and the method of recording the creep curves is important, especially when, as a result of the increase in temperature and/or the increase in stress, the deformation value increases and the shape of the creep curves changes, and due to the rate of changes, 


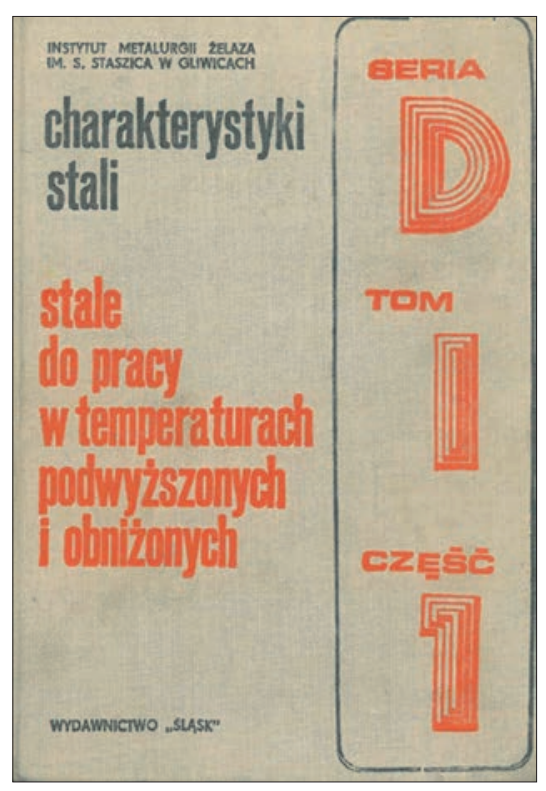

Fig. 1. "Charakterystyki stali - stale do pracy $w$ temperaturach podwyższonych i obniżonych [Steel characteristics - steels for operation at elevated and lowered temperatures]" - study by IMż

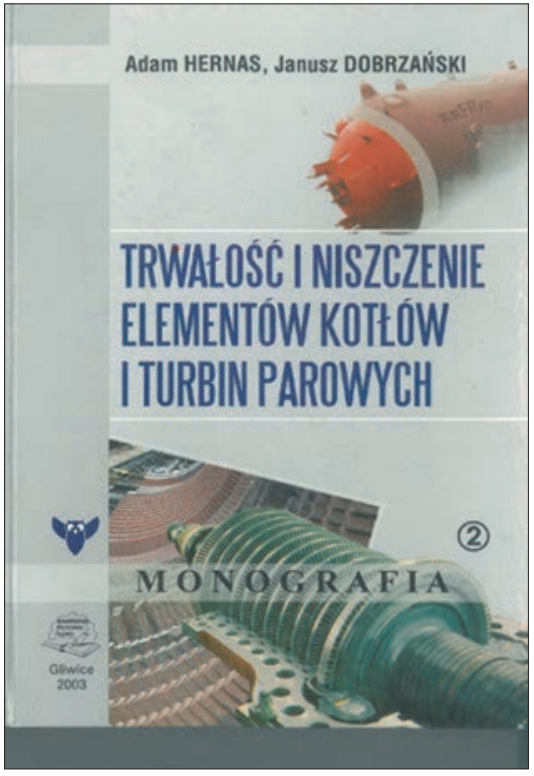

Fig. 3. "Trwałość i niszczenie elementów kotłów i turbin parowych cz. II [Durability and destruction of components of boilers and steam turbines, part II]"

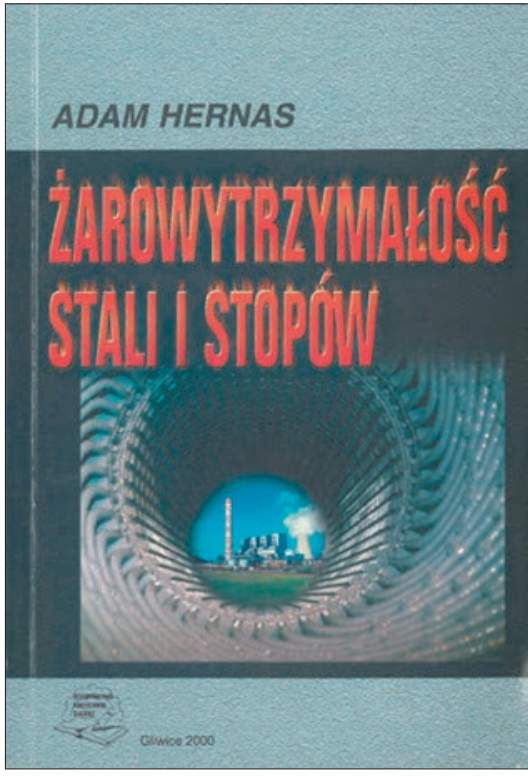

Fig. 4. "Żarowytrzymałość stali i stopów [Creep resistance of steels and alloys]", 2000 the creep curve may be difficult to record and the obtained result may be difficult to interpret.

Diagnostic tests of devices operating in creep conditions are an important area of activity of the Łukasiewicz - IMŻ's Department of Materials Research for Power Engineering. The role of cooperation between IMŻ and the Silesian University of Technology should be emphasised here. Professor Adolf Maciejny, an outstanding scientist in the study of materials for the power industry, employee of the Faculty of Metallurgy and Materials Science in Katowice, published his first work on the study of the structure of Cr-Mo-V steel using the replica technique in 1968. He directed his doctoral students, including Professor Adam Hernas, toward many years of effective cooperation with the Institute of Ferrous Metallurgy.

This resulted in numerous works and projects concerning research methods used in the diagnostics of pressure components of power devices, development of new materials for the power industry and the processes of their

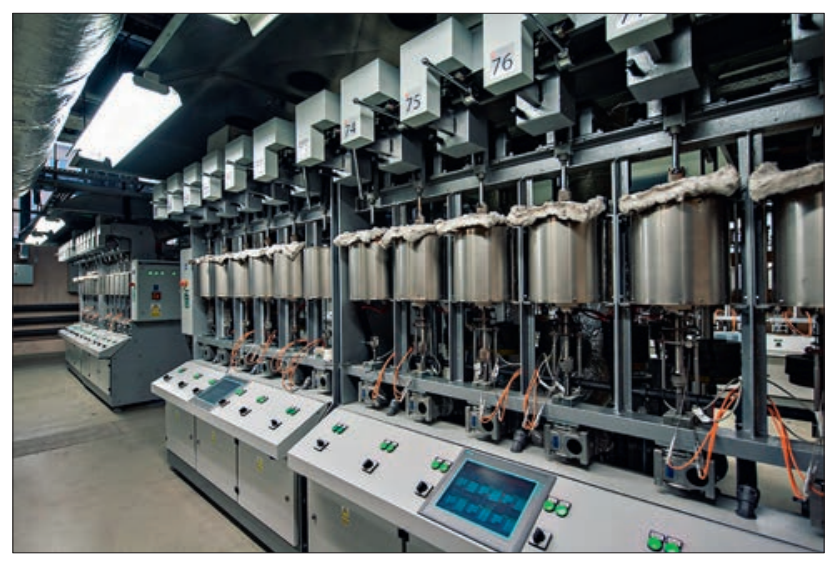

Fig. 2. Six-stand single-sample machines for creep tests manufactured by IMż

Rys. 2. Sześciostanowiskowe jednopróbkowe maszyny do prób pełzania produkcji własnej IMŻ destruction [7-13]. Particularly noteworthy is the first joint study by Professors A. Hernas and J. Dobrzański: "Trwatość i niszczenie elementów kottów i turbin parowych cz. II [Durability and destruction of components of boilers and steam turbines, part II]", 2003 (Fig. 3), which is a continuation of part I of the monograph published by the Silesian University of Technology in 2000, "Żarowytrzymałość stali i stopów [Creep resistance of steels and alloys]" by Professor A. Hernas (Fig. 4). The issues described in the monographs concerned specific components of the boiler and turbine, which described the steels used in the power industry, the processes of their destruction, diagnostics and methods for assessing residual life and the basis for forecasting the extended operation time of the structural components in question. In these studies, the authors used the actual results of research and analyses of materials subjected to long-term use under operating conditions. This subject is still being developed at the Institute of Ferrous Metallurgy in cooperation with numerous domestic and foreign research centres. This resulted in numerous lectures at industry conferences and scientific publications in renowned international journals [14-23].

In 2011, Professor Janusz Dobrzański published the monograph "Materiałoznawcza interpretacja trwałości stali dla energetyki [Material science interpretation of the durability of steel for the energy sector]", in which he summarised his over 30 years of scientific activity in the field of materials and research in the energy sector (Fig. 5). At the same time, this publication has become a benchmark in ordering material research and research methods applied by users of energy devices in the domestic power industry. Professor Dobrzański's study, presented at numerous industry conferences, contributed to a wider cooperation between IMŻ and the Silesian University of Technology with the Office of Technical Inspection. This resulted in the development of "Wytyczne Urzędu Dozoru Technicznego nr 1/2015 [Guidelines of the Office of Technical Inspection No. 1/2015]. Zasady diagnostyki i oceny trwatości eksploatacyjnej elementów kottów i rurociagów pracujacych $w$ warunkach petzania [Guidelines of 


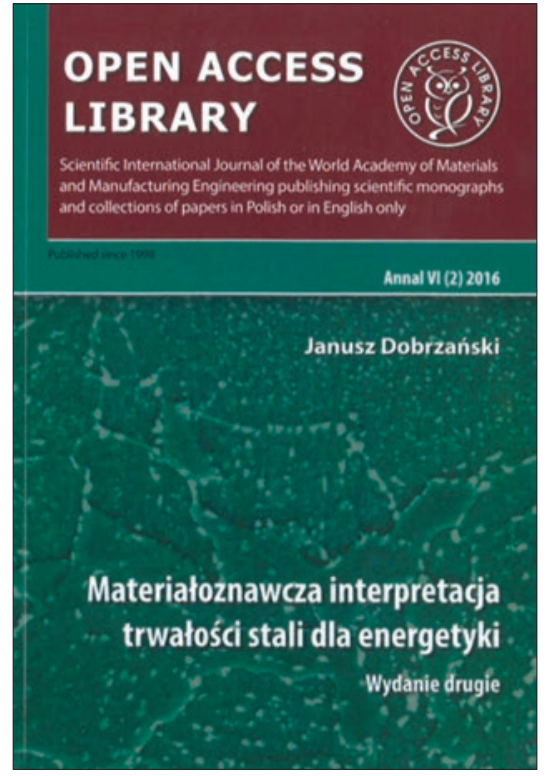

Fig. 5. "Materiałoznawcza interpretacja trwałości stali dla energetyki [Material science interpretation of the durability of steel for the energy sector]", 2011

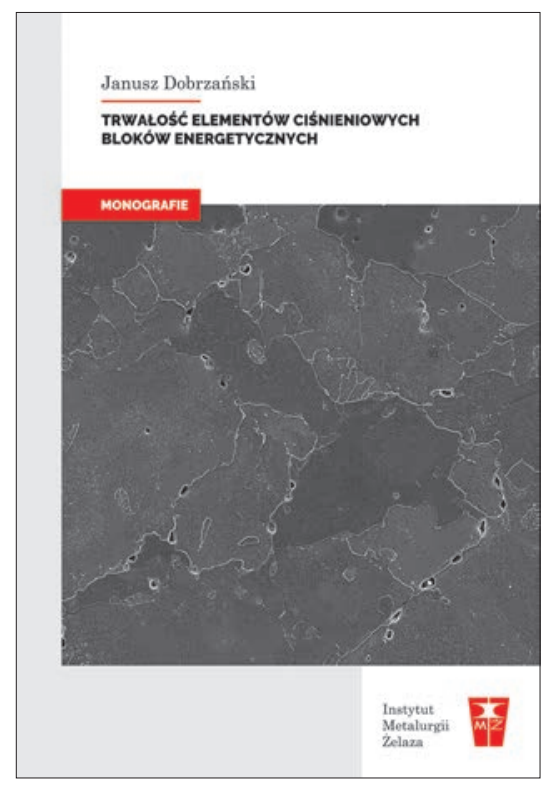

Fig. 8. "Trwałość elementów ciśnieniowych bloków energetycznych [Durability of pressure components of power units]", 2019

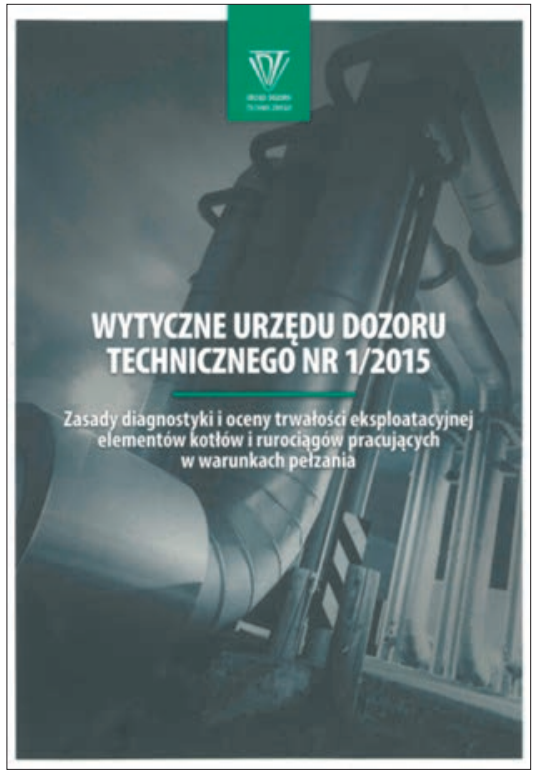

Fig. 6. "Wytyczne Urzędu Dozoru Technicznego nr 1/2015 [Guidelines of the Office of Technical Inspection No. 1/2015] [Guidelines of the Office of Technical Inspection No. 1/2015]"

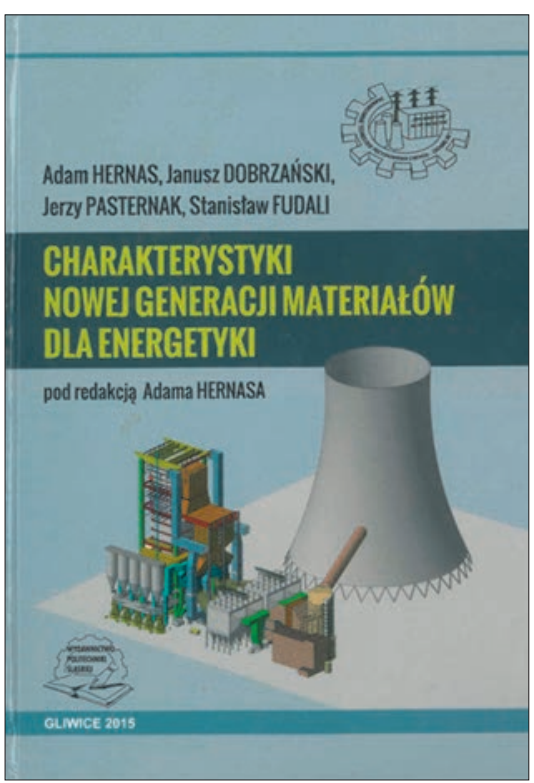

Fig. 9. Charakterystyki nowej generacji materiałów dla energetyki [Characteristics of the new generation of materials for the energy sector], 2015

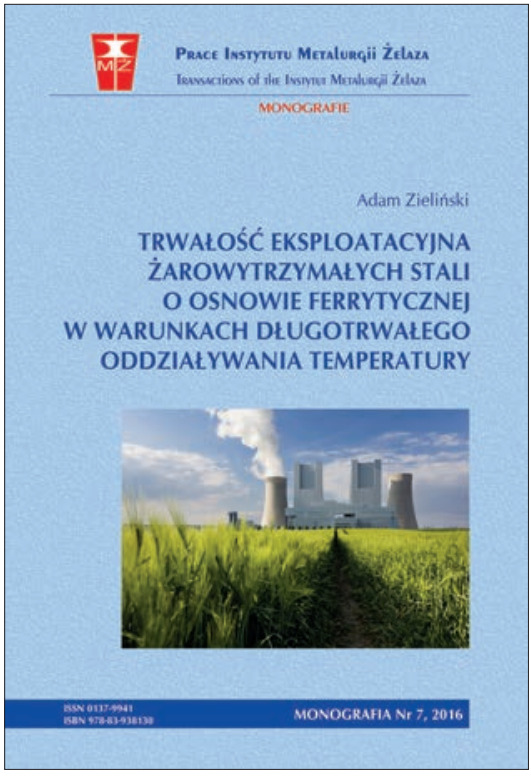

Fig. 7. "Trwałość eksploatacyjna żarowytrzymałych stali o osnowie ferrytycznej w warunkach długotrwałego oddziaływania temperatury [Service life of refractory ferritic matrix steels under long-term temperature]", 2016

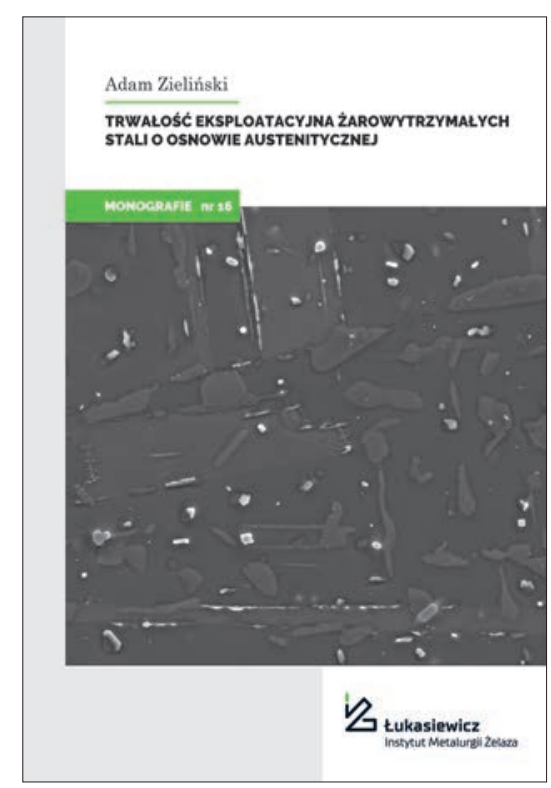

Fig. 10. "Trwałość eksploatacyjna żarowytrzymałych stali o osnowie austenitycznej [Service life of heat-resistant austenitic steels]", 2021 the Office of Technical Inspection No. 1/2015. Principles of diagnostics and evaluation of service life of components of boilers and pipelines operating in creep conditions]" in cooperation with UDT Management (Fig. 6). They constitute the basis for the requirements for the preparation of the necessary program and the scope of tests and methods for assessing the condition of a material after long-term use. As a result, they are used to determine the objective suitability for further operation of structural components, both before and after reaching the design working time, as well as in the event of a failure related to excessive loss of service life or the formation of material discontinuities. The publication of the guidelines ended the time of harmful 'freedom' in diagnostic works and allowed UDT inspectors to set the same technically justified test conditions, which significantly influenced operational safety.

The success of the first part of the UDT Guidelines and subsequent studies by IMŻ in the field of implementing research methodologies and conducting research on new generation steels, including the original monograph by Adam Zieliński, PhD, Eng., "Trwatość eksploatacyjna żarowytrzymatych stali o osnowie austenitycznej [Service life of refractory ferritic matrix steels under long-term temperature]", 2016 (Fig. 7), and another monograph by Professor J. Do- 
brzański, "Durability of pressure components of power units", 2019, (Fig. 8) resulted in the commencement of work on the development of the next, second part of the Guidelines, extended by modern steel grades used in supercritical power industry (publication planned in December 2021).

Legal conditions related to stricter environmental requirements, ensuring the country's energy security and improvement of technical and economic indicators with a significantly decapitalised state of the domestic energy sector made it necessary to take effective investment and modernisation measures. These challenges were the basis for the launch of numerous works and research projects at IMŻ, among others with the Silesian University of Technology, Cracow University of Technology and Fabryka Kotłów Rafako S.A., in the field of implementing new steels and alloys with austenitic matrix. The first such study, covering, among other, the basic properties of these materials and techniques of their joining, is presented in the monograph edited by A. Hernas, "Charakterystyki nowej generacji materiałów dla energetyki [Characteristics of the new generation of materials for the energy sector]”, 2015, (Fig. 9).

The materials obtained at that time and their insightful, long-term research were published in the monograph of Associate Professor Adam Zieliński, Eng.: “Trwatość eksploatacyjna żarowytrzymatych stali o osnowie austenitycznej [Service life of heat-resistant austenitic steels]", 2021 (Fig. 10).

An important part of the research work and studies carried out at Łukasiewicz - IMŻ in cooperation with numerous research centres in the country is, above all, the practical aspect in line with the idea of the Patron of the Institute, Stanisław Staszic - "The importance of science relies on its practical usefulness". Therefore, these studies are aimed at determining/estimating service life for various states of microstructure degradation and mechanical properties of materials used at elevated and high temperatures. They allow determining the time of safe operation of components operating in creep conditions, both within the design working time and outside the design working time.

\section{CURRENT RESEARCH DIRECTIONS}

The period of time necessary for the development and commissioning of a new type of material for operation under creep conditions usually ranges from a few to several years. This is mainly due to the necessity to carry out long-term studies of the influence of temperature, stress and working environment on the degradation of the microstructure, which directly results in a change in performance. Therefore, the operation of new power units and modernisation of old units, in order to increase their operating parameters and often maintain the current state, require comprehensive verification and continuous supplementation of material characteristics of the used steels and alloys in terms of their suitability for long-term operation.

The above information justifies the current research directions of the Department of Materials Research for Power Engineering of Łukasiewicz - IMŻ, which can be included in five areas:

- Research on long-operated materials in Poland, the operation time of which significantly exceeded the design working time of 100 and 200 thousand hours).

- Research on new generation ferritic matrix materials implemented in the domestic power industry during the construction of boilers with supercritical parameters, the operation time of which in the domestic power industry does not exceed the design working time.

- Research on new generation austenitic matrix steels implemented in the domestic power industry during the construction of boilers with supercritical operating parameters, the operating time of which in the domestic power industry does not exceed 30,000 hours of operation.

- Research on new generation steels and alloys with austenitic matrix recommended for use in the construction of boilers with supercritical operating parameters with efficiency above $50 \%$.

- Development of research methodologies in the assessment of the service life of devices operating in creep conditions.

\section{REFERENCES}

[1] A. Zieliński. Trwatość eksploatacyjna żarowytrzymatych stali o osnowie ferrytycznej $w$ warunkach długotrwatego oddziatywania temperatury. Gliwice: Wyd. Instytutu Metalurgii Żelaza, Monographs, No. 7, 2016.

[2] A. Hernas. Żarowytrzymatość stali i stopów. Gliwice: Wydawnictwo Politechniki Śląskiej, 2000.

[3] Polski Komitet Normalizacyjny. PN-EN ISO 204:2018-11. Metale - Próba petzania przy jednoosiowym rozciaganiu - Metoda badania. Warszawa: PKN, 2018.

[4] A. Zieliński, G. Golański, M. Sroka. Comparing the methods in determining residual life on the basis of creep tests of low-alloy $\mathrm{Cr}-\mathrm{Mo}-\mathrm{V}$ cast steels operated beyond the design service life. International Journal of Pressure Vessels and Piping, 2017, 152, p. 1-6.

[5] A. Zieliński, G. Golański, M. Sroka, J. Dobrzański. Estimation of long-term creep strength in austenitic power plant steels. Materials Science and Technology, 2016, 32 (8), p. 780-785.

[6] J. Dobrzański. Materiałoznawcza interpretacja trwałości stali dla energetyki. Open Access Library, 2011, 3.

[7] Targeted Project No. 7 T08B 2542000 C/5153 (2001-2003): "Modernizacja węzłów przegrzewaczy instalacji ciśnieniowej wysokoprężnych kotłów parowych".

[8] Development Project No. R 0601203 (2007-2010): “Opracowanie systemu oceny stanu materiału i przewidywanie czasu bezpieczne eksploatacji ciśnieniowych elementów i urządzeń energetycznych pracujących w podwyższonej temperaturze”.
[9] COST 536 Action (2005-2009): Alloy development for critical of environmentally friendly steam power plant, PL2 "Mechanical and creep testing of new Steels and Welds".

[10]COST 538 Action (2005-2008): "High Temperature Plant Life time Extension", WP2 Ferrous Material Degradation-Forecasting of life and residual life of material and welded joints of power boiler pressure section components after long-term service at creep conditions.

[11] NR15-0060-10/2010: “Ocena zachowania się i prognoza długotrwałej pracy stali nowej generacji na elementy kotłów eksploatowanych powyżej temperatury granicznej”, 2010-2013.

[12] PBS3/B5/42/2015.: "Methodology, evaluation and prognosis of operation beyond the design working time of welded joints of pressure elements of power boilers," 2015-2017.

[13] 2011/01/D/ST8/07219: “Modelowanie trwałości materiałów dla nowoczesnej energetyki na podstawie prób pełzania”, 2011-2016.

[14]A. Zieliński, G. Golański, M. Sroka. Influence of long-term ageing on the microstructure and mechanical properties of T24 steel. Materials Science and Engineering: A., 2017, 682, p. 664-672.

[15] G. Golański, A. Zielińska-Lipiec, A. Zieliński, M. Sroka. Effect of Long-Term Service on Microstructure and Mechanical Properties of Martensitic 9\% Cr Steel. Journal of Materials Engineering and Performance, 2017, 26, p. 1101-1107. 
[16]T. Dudziak, V. Deodeshmukh, L. Backert, N. Sobczak, M. Witkowska, W. Ratuszek, K. Chruściel, A. Zieliński, J. Sobczak, G. Bruzda. Phase Investigations Under Steam Oxidation Process at $800^{\circ} \mathrm{C}$ for $1000 \mathrm{~h}$ of Advanced Steels and Ni-Based Alloys. Oxidation of Metals, 2017, 87 (1-2), p. 139-158.

[17]A. Zieliński, M. Sroka, A. Hernas, M. Kremzer. The effect of longterm impact of elevated temperature on changes in microstructure and mechanical properties of HR3C steel. Archives of Metallurgy and Materials. 2016, 61 (2), p. 761-765.

[18]A. Zieliński, G. Golański, M. Sroka, J. Dobrzański. Estimation of long-term creep strength in austenitic power plant steels. Materials Science and Technology, 2016, 32 (8), p. 780-785.

[19]H. Purzyńska, G. Golański, A. Zieliński, J. Dobrzański, M. Sroka Precipitation study in Ti-stabilised austenitc stainless steel after 207,000 h of service. Materials at High Temperatures, 2019, 36 (4), p. 296-303.
[20]P. Duda, Ł. Felkowski, A. Zieliński, A. Duda. An analysis of a reheater failure and proposal to upgrade the device design. Energies, 2019, 12, 2255.

[21]M. Dziuba-Kałuża, A. Zieliński, J. Dobrzański, M. Sroka, P. Urbańczyk, A. Śliwa. Residual life of boiler pressure parts made of the 13CrMo4-5 steel after long-term operation in a creep conditions. Archives of Metallurgy and Materials, 2018, 63 (2), p. 889-897.

[22]M. Kierat, A. Zieliński. Podwyższona temperatura i długotrwały wpływ procesu starzenia na zmiany w mikrostrukturze stopu HR6W. Journal of Metallic Materials, 2019, 71 (2), p. 8-13.

[23]A. Jasiński, A. Zieliński, H. Purzyńska. Residual life of repair welded joints in pipelines made of 13HMF after use for the design operating time. Transactions of the Instytut Metalurgii Żelaza, 2018, 70 (3), p. 2-10. 